\title{
DESTINATION MANAGEMENT ORGANISATIONS (DMOS) AND THEIR ROLE IN SUMMER PRODUCT DEVELOPMENT IN SELECTED ALPINE COUNTRIES
}

\author{
KATARZYNA KLIMEK \\ Cracow University of Economics, Kraków, POLAND \\ e-mail: kklimek@uek.krakow.pl
}

RECEIVED
ACCEPTED
JEL
CLASSIFICATION

KEYWORDS

ABSTRACT
30 May 2017

12 November 2017

L83, L98

Alpine DMOs, summer mountain tourism, dynamic packaging

Appeared in the XIX century, summer mountain tourism has a very strong capital attraction for international tourist flows and constitutes the basis of leisure tourism. However, for the last several years numerous, mature Alpine destinations in particular have been losing overnight stays during summer months by cause of competition with winter tourism as well often from warmer, cheaper and more easily accessible beach destinations. Moreover, due to the globalisation pressure, summer mountain tourism development is strongly dependent on structural change in "21st century post-modern" tourist demand.

Thus, innovative tourism product development has become a central key issue for many Alpine tourism organisations. The aim of this paper is to present the result of explanatory research conducted in 2014 and 2015 in four Alpine countries. The research objective was to evaluate the role of 125 Destinations Management Organizations (DMOs) in the stimulation of summer tourism through the commercialization of various tourism products.

\section{Introduction}

The dominance of winter tourism and the decline in summer tourism is observed since the mid-1960s, in many Alpine areas (Needham, Rollins, Ceurvorst, Wood, Grimm, Dearden, 2010; Schuckert, Möller, Weiermair, 2007). In French mountain regions for example the number of overnights in summer has decreased by $10 \%$ over the last ten years, i.e. 12 million overnights (Berthier, 2014; ODIT France, 2011). Moreover, Alpine regions in summer season are in strong competition with often cheaper and weather guaranteed destinations at seaside (Marrocu, Paci, 2013). 
Besides, rapid development of communication technology (ICT) and easy access to information has radically changed the travel consumption habits (Pearce, 2011). Thanks to the easy internet access, contemporary travellers are becoming empowered consumers capable to compare the value of various tourist products and often to bundle online holiday stays themselves (Ferreira, Putnik, Cruz-Cunha, Putnik, 2012).

In this context, holistic destination management and multi-channel e-distribution of offers have become central issue especially for many mature Alpine destinations (Grissemann, Pikkemaat, Weger, 2013).

The main objective of this paper is to present the result of comparative research which was done in 2014 and 2015 into 125 Alpine DMOs, in order to evaluate their efforts regarding product commercialization to stimulate summer tourism development.

\section{Litepature review}

For many years, the trend for skiing in winter and beach stays in summer has had a direct repercussion on seasonality and disproportion between winter and summer tourist flows in Alpine areas (Bausch, Unseld, 2017; Béchet, Margretier, 2013). Despite the seasonal imbalance of tourist arrivals, winter tourism generates greater economic income and better supports development of several mountain resorts by financing of the infrastructure and job creation (Hallmann, Mueller, Peters, 2015; Zehrer, Smeral, Hallmann, 2016). However, the negative impact of seasonality affects all aspects of supply-side behaviour: finance, labour market and stakeholder operations (Boffa, Succurro, 2012; O'Mahony, Galloway, Bergin-Seers, Lee, McMurray, 2008). Hence, as stated by Beritelli, (2011) and Needham, Rollins, (2005), nowadays Alpine reception areas are multifaceted and their supply chain is often fragmented into various interest groups. Several studies show also the lack of clear positioning of Alpine regions, particularly in the development of summer tourism (Egger, Anthamatten, 2013; Muhar, Schauppenlehner, Brandenburg, Arnberger, 2007). Thus, it is very important to determine the role of DMOs and their key stakeholders in order to build common vision in long-term destination governance (Beritelli, Buffa, Martini, 2015; Leasser, Beritelli 2013). The concept of DMO has been widely described in the literature. It refers to coalition of public and private partners who are acting together to achieve mutual goals (Beritelli, Bieger, Laesser, 2007, UNWTO 2007). The main role of a DMO refers to the coordination of long-term destination marketing and management, since the consumer perceives and buys a destination as one integrated product (Bieger, Beritelli \& Leasser 2009).

One of the most important challenges for Alpine tourism organisations is also the technological advances in information and communication technologies (ICT) which have radically changed the way the tourism products are created, offered and purchased (Law, Buhalis, Cobanoglu, 2014). Lack of loyalty, increasing expectations for individualized holidays (often in the form of dynamic packaging) and sharing new experiences, seem to be the most important features of contemporary tourist demand (Atembe, Akbar, 2014; Parvaneh, Arentze \& Timmermans, 2012). Thus, DMOs have to face these challenges with appropriate product diversification and e-commercialization strategies (Dwyer, Edwards, 2009; Flagestad, 2006; Tanti, Buhalis, 2016).

Taking in consideration all those challenging aspects stated in literature which contemporary Alpine tourism organisations are confronted with, this research aimed at finding answers to the following questions:

- What kind of summer offers do Alpine DMOs commercialize through their websites?

- What are the drivers concerning development of summer packages in four selected countries and what type of summer offers have the greatest sales potential? 
- Do Alpine DMOs implement dynamic packaging?

- What are the most important barriers concerning commercialization of dynamic solutions?

\section{Methodology and data collection}

The literature review and discussions with managers from several Alpine DMOs have been the basis for the development of the overall study design.

The quantitative research (using benchmark study and an online survey) was conducted in 49 Austrian, 5 German, 24 French and 47 Swiss DMOs from April 2014 to October 2015. The sample selection was intentional and referred to the author's earlier studies conducted in mature Alpine destinations from 2011 to 2013 (Klimek, 2013).

The benchmark analysis of 125 Alpine DMO websites was carried out in the first step of the study. This analysis was based on the detailed criteria which refereed to the summer product development. In the second step, an online questionnaire entitled "New challenges for Alpine DMOs in summer tourism development" was created. The survey composed of 52 questions (in French and German) was sent to 125 DMO managers. The return rate amounted to $52.8 \%$, which means that 66 organizations participated in the study. The structure of the sample by country is presented in Table 1.

Table 1. Characteristics of the research sample of the survey

\begin{tabular}{lcc}
\hline \multicolumn{1}{c}{ Country } & Number of analysed DMOs & $\%$ \\
\hline Switzerland & 34 & 52 \\
Austria & 16 & 24 \\
France & 12 & 18 \\
Germany & 4 & 6 \\
Total & 66 & 100 \\
\hline
\end{tabular}

Swiss DMO managers have responded to a greater extent to the questionnaire, which consisted $52 \%$ of the total sample. Therefore, the comparative analyses presented below were performed between two groups: Swiss and other Alpine countries tourist organisations (comprising Austrian, French and German DMOs).

\section{Discussion of findings}

Benchmark study of Alpine DMO websites indicates the three following types of summer offers commercialized by these organizations:

1. Accommodation offers available in different type of lodging.

2. Pre-composed "static" packages, i.e. simple or multicomponent packages sold by DMOs at a flat price.

3. Dynamic packages, i.e. the combination of different travel components, bundled and priced online in real time. More than $90 \%$ of analysed Swiss and other Alpine tourism organizations use various online engines to sell different types of accommodation. The widest range of lodging is proposed online by Austrian DMOs, i.e. stays in pensions, INNs, B\&Bs, farms, holiday homes, guest houses, shelters, camping etc.

As regards the summer offers, the analysis of destination proposals show that $82.5 \%$ of DMOs under study provide through their websites a huge variety of summer packages. 
Three principal types of summer offers developed by all Alpine DMOs under study refer to traditional mountain activities, i.e. hiking, biking and family stays. But, thanks to the original programming of these packages (themed walks, arranged touring, experiential stays, and 4 season health offers), as well as introduction of summer cards (offering various discounts), some destinations aim to better differentiate (e.g. Allgäu, Tyrol, Rhône-Alpes).

In addition, several mountain resorts attract tourists by a new form of water holidays.

Especially, new exploitation of Swiss, Austrian and French mountain lakes (artificial beaches, palm trees) are becoming an alternative to the overcrowded beaches of costal destinations.

However, according to the surveyed DMO managers, summer products with the greatest sales potential are the simple packages composed of two services e.g. accommodation and cable car facilities or accommodation with board (see Table 2).

Table 2. Sales potential of summer tourist products specified by DMO surveyed managers

\begin{tabular}{lcc}
\hline \multicolumn{1}{c}{ Summer tourist products } & Other Alpine Countries & Switzerland \\
\hline Summer simple packages (e.g. accommodation with board, & 4.80 & 4.91 \\
or accommodation with cable car offer) & 3.43 & 3.40 \\
Summer multicomponent packages & 3.61 & 3.54 \\
Booking of hotel rooms & 3.81 & 3.95 \\
Booking of self-catering lodging & 3.00 & 3.44 \\
Last minute offers & 4.25 & 4.54 \\
Local attractions \& animations & 3.40 & 3.40 \\
Cable car \& public transport offer & 4.41 & 4.45 \\
Others summer products, e.g. MICE\&group offers & & \\
\hline
\end{tabular}

Evaluation of scale modalities: 1 (very small); 2 (small); 3 (medium); 4 (big); 5 (very big)

As regards to the multicomponent packages proposed on destination websites, they are often considered by tourists as a source of additional information about the place itself, but not as an interesting product to buy. That is the reason why for the majority (86\%) of Swiss and (84\%) other Alpine DMO managers, packages composed of multiple services represent sales potential of medium importance.

It could be also related to the growing importance of online travel agencies (OTAs), e.g. Booking.com, Expedia, Tripadvisor, etc., which have become key market players as regards online holiday packages (Beritelli, Schegg, 2016).

Besides, as stated by Cohen, Prayag, Moital, (2014) and many other authors throughout the literature, structural change in contemporary tourist demand, i.e. need for freedom in taking travel decisions, has a direct impact on tourists' booking habits. That is why before coming to the holiday destination, travellers mainly book simple packages, while various summer offers are purchased spontaneously during their stay (Choi, Lehto, Morrison, Jang, 2012).

Surveyed managers identified also five elements essential for successful commercialization summer offers (see Table 3). 
Table 3. Key elements important for successful commercialization of summer travel packages in Alpine destinations

\begin{tabular}{lcc}
\hline \multicolumn{1}{c}{ Summer tourist products } & Other Alpine Countries & Switzerland \\
\hline Flexibility of services (related to duration of stay, number of participants, easy booking) & 3.56 & 4.06 \\
Originality of the offers based on local "learning by doing" activities & 4.56 & 4.55 \\
Quality\&price optimization and good price value & 4.58 & 4.34 \\
Facilitation for client, e.g. transport of luggage & 4.60 & 4.51 \\
The importance of dynamic packaging & 4.61 & 4.65 \\
\hline multi-stakeholders' cooperation & & \\
\hline
\end{tabular}

Evaluation of scale modalities: 1 (not at all important); 2 (unimportant); 3 (fairly important); 4 (important); 5 (very important)

Besides, transport facilitation, originality and price optimization of summer offers, $59 \%$ of surveyed DMOs managers emphasized the importance of the dynamic packaging. Certainly, "tailor made" packages have become sought by tourists but, such innovative offers seem to be a challenging task for many Alpine DMOs under study. Indeed, among 66 analysed destinations, only five DMOs (four in Switzerland and one in Germany) have implemented dynamic packaging in the summer season ${ }^{1}$.

It can be attributed to the fact that dynamic packaging requires sophisticated technical equipment and permanent supply chain management based on constant collaboration between DMOs and relevant service providers (Angst, Skalski 2016; Markus, Lassing, 2008). Moreover, for the implementation and maintenance of a dynamic system, significant financial resources are required, which especially small Alpine DMOs often cannot afford (Qirici, Theodhori, Elmazi, 2011). One-third of surveyed Alpine DMO managers find the dynamic e-solutions difficult to introduce from the financial point of view.

Besides, $38 \%$ of Swiss and 36\% of other Alpine countries DMO managers declare that currently there is not sufficient teamwork and cooperation between DMOs and their stakeholders to implement dynamic offers (Figure 1).

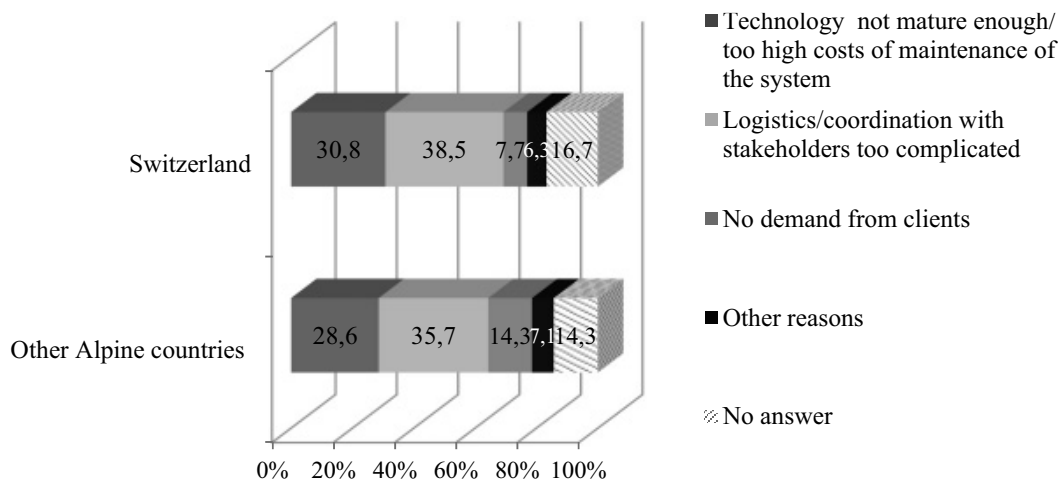

Figure 1. The most important barriers related to the implementation of dynamic packaging in Alpine destinations (in \%)

${ }^{1}$ Dynamic Alpine destinations in the summer season are: Adelboden, Davos-Klosters, Flims-Laax-Falera, Verbier SaintBernard in Switzerland and Obersdorf in Germany. 
Hence, for the majority of analysed DMOs it is much easier to commercialize their summer tourist offers in the form of pre-composed packages i.e. consisting of a determined number of services and sold by DMOs at a flat rate ${ }^{2}$.

\section{Conclusion}

The results show that numerous Alpine DMOs which were taken into account in the research study, fight against summer season stagnation by the development of various types of tourist offers. Internet and modern ICT solutions seem to play an important role in their summer product development portfolio. Yet, as shown by the survey results, summer Alpine offers are mostly developed in the form of pre-composed, "static" packages and their sales potential is rather moderate.

The reasons for this can be mostly associated with growing importance of OTAs and a variety of internet platforms which allow tourists to bypass DMOs offers for often cheaper and more personalised travel alternatives (Beritelli, Schegg, 2016; Wang, Fesenmaier, 2013). Thus, according to the surveyed DMO managers, the originality of summer products, their quality and price optimization and "tailor made" dynamic packages, seem to be key issues for commercialization of destination summer offers.

However, e-packaging remains a challenging task for the majority of Alpine destinations. The shift to the e-innovation will not be possible without wide and long-term collaboration between public and private stakeholders. All surveyed DMO managers have emphasized this issue as a mandatory condition on the way to overcome seasonality. Thus, despite of the revealed barriers, $61 \%$ of surveyed Swiss and $58 \%$ of other Alpine DMOs plan to introduce dynamic packaging in the near future.

Due to limited amount of study cases the generalization should be taken with care. The examples of Alpine DMOs' product development presented in the paper can, however, constitute to an interesting reference for other European peripheral, mountain areas. Indeed, it would help to develop in those areas more innovative products management system based on innovative ICT solutions.

\section{References}

Angst, S., Sealskin, V. (2016). e-Commerce \& Sales in Tourism. Destination-Dynamic Packaging. Chur: Amadeus IT Group SA.

Atembe, R., Akbar, B. (2014). Tourists Co-creation Experiences Onsite-Enabled by Mobile Devices. In: Information and Communication Technologies in Tourism 2014, 20-28.

Bausch, T., Unseld, C. (2017). Winter tourism in Germany is much more than skiing! Consumer motives and implications to Alpine destination marketing. Journal of Vacation Marketing, 21-30.

Béchet, M., Margretier, J. (2013). The Future of the Alps: New markets and new products. Paper presented at the Alps Tourism Expert Days, Chamonix, September 2013.

Beritelli, P. (2011). Cooperation among prominent actors in a tourist destination. Annals of Tourism Research, 607-629.

Beritelli, P., Bieger, T., Laesser, C. (2007). Destination governance: using corporate governance theories as a foundation for effective destination management. Journal of Travel Research, 96-107.

Beritelli, P., Buffa, F., Martini, U. (2015). The coordinating DMO or coordinators in the DMO? - An alternative perspective with the help of network analysis. Tourism Review, 24-42.

Beritelli, P., Schegg, R. (2016). Maximizing online bookings through a multi-channel-strategy: Effects of interdependencies and networks. International Journal of Contemporary Hospitality Management, 68-88.

${ }^{2}$ Despite the selection of the length of stay, the number of participants, the type of accommodation and the categories of meals, the customer usually cannot change the number of services included in static package. 
Bieger, T., Beritelli, P., Leasser, C. (2009). Size matters! Increasing DMO effectiveness and extending tourism destination boundaries. Tourism Review, 309-327.

Berthier, J. (2014). L'adaptation des stations françaises de ski au tourisme d'été: défis et actions. Paper presented at the 8th edition of the World Congress on Snow and Mountain Tourism. Andorra, April 2014.

Boffa, F., Succurro, M. (2012). The impact of search cost reduction on seasonality. Annals of Tourism Research, 1176-1198.

Choi, S., Lehto, C., Morrison, A., Jang, S. (2012). Structure of travel planning processes and information use patterns. Journal of Travel Research, 26-40.

Cohen, S., Prayag, G., Moital, M. (2014). Consumer behaviour in tourism: Concepts, influences and opportunities. Current Issues in Tourism, 872-909.

Dwyer, L., Edwards, D. (2009). Tourism product and service innovation to avoid 'strategic drift'. International Journal of Tourism Research, 321-335.

Egger, T., Anthamatten, C. (2013). Ein Road-map zur Wiederentdeckung des Alpintourismus. Bern: SAB.

Ferreira, L., Putnik, G., Cruz-Cunha, M., Putnik, Z. (2012). Towards effective tourism dynamic packages. Information Resources Management Journal, 1-21.

Flagestad, A. (2006). The destination as an innovation system for non-winter tourism. Innovation and Product Development in Tourism, 26-38. Berlin: Erich Schmidt Verlag.

Grissemann, U., Pikkemaat, B., Weger, C. (2013). Antecedents of innovation activities in tourism: An empirical investigation of the Alpine hospitality industry. Tourism, 7-27.

Hallmann, K., Mueller, S., Peters, M. (2015). The Assessment of Competitiveness: The Case of Three Alpine Winter Sports Destinations. Tourism Analysis, 20 (6), 677-687.

Klimek, K. (2013). Destination Management and Sustainable Tourism Development. A cross-country analysis. Saarbrücken: LAP Lambert Academic Publishing.

Law, R., Buhalis, D., Cobanoglu, C. (2014). Progress on information and communication technologies in hospitality and tourism. International Journal of Contemporary Hospitality Management, 27-750.

Laesser, Ch. Beritelli, P. (2013). St. Gallen Consensus on Destination Management. Journal of Destination Marketing \& Management, 46-49.

Markus, M., Lassnig, M. (2008). Some Critical Remarks on Dynamic Packaging from the Perspective of SMEs and Small Tourism Destinations. In: Information and Communication Technologies in Tourism 2008. Springer.

Marrocu, E., Paci, R. (2013). Different tourists to different destinations. Evidence from spatial interaction models. Tourism Management, 71-83.

Muhar, A., Schauppenlehner, T., Brandenburg, C., Arnberger, A. (2007). Alpine summer tourism: the mountaineers' perspective and consequences for tourism strategies in Austria. Forest Snow and Landscape Research, 7-17.

Needham, M., Rollins, R. (2005). Interest group standards for recreation and tourism impact at ski areas in the summer. Tourism Management, 1-13.

Needham, M.D., Rollins, R.B., Ceurvorst, R.L., Wood, C.J., Grimm, K.E., Dearden, P. (2010). Motivations and normative evaluations of summer visitors at an alpine ski area. Journal of Travel Research, 50 (6), 669-684.

O'Mahony, B., Galloway, G.A., Bergin-Seers. S., Lee, C., McMurray, A. (2008). Seasonality in the tourism industry. Impacts and strategies. CRC for Sustainable Tourism.

Odit France (2011). Observatoire, Domaine skiable de France. Paris.

Parvaneh, Z., Arentze, T., Timmermans, H. (2012). Understanding travelers' behavior in provision of travel information: A Bayesian belief approach. Procedia-Social and Behavioral Sciences, 251-260.

Pearce, P. (2011). Tourist behaviour and the contemporary world. Bristol: Channel View Publications.

Schuckert, M., Möller, C., Weiermair, K. (2007). The identification of Alpine destination life cycles: challenges and implications. Trends and Issues in Global Tourism, 121-136.

Tanti, A., Buhalis, D. (2016). Connectivity and the Consequences of Being (Dis) connected. In: Information and Communication Technologies in Tourism 2016 (pp. 31-44). Springer.

Qirici, E., Theodhori, O., Elmazi, L. (2011). E-Marketing and ICT-Supported tourist destination management. Implications for tourism industry in global recession. International Journal of Management Cases, 152-158.

UNWTO. (2007). A Practical Guide to Tourism Destination Management. Madrid. 
Wang, D., Fesenmaier, D.R. (2013). Transforming the travel experience: The use of smartphones for travel, In: Information and Communication Technologies in Tourism 2013 (pp. 58-69). Springer.

Zehrer, A., Smeral, E., Hallmann, K. (2016). Destination Competitiveness A Comparison of Subjective and Objective Indicators for Winter Sports Areas. Journal of Travel Research, 1-12.

Cite this article aS: Klimek, K. (2017). Destination Management Organisations (DMOs) and their role in summer product development in selected Alpine countries. European Journal of Service Management, 4 (24), 31-38. DOI: 1.18276/ejsm.2017.24-05. 